\title{
Minas Gerais: a case of success in technological innovation in Brazil
}

\author{
Amanda Luisa da Fonseca and Fernando de Pilla Varotti* \\ Núcleo de Pesquisa em Química Biológica, Universidade Federal de São João del-Rei, Divinópolis, Brazil
}

\begin{abstract}
Technological innovation is essential for organizations that want to gain relevance in the market in which they act whether it is educational or business. To grow and stand out, an organization needs to innovate. Innovation allows them to gain a significant competitive advantage, especially when it comes to technology. At present there is great development of new technologies that transform the environment, which stimulates the investment in technological innovation. The constant need to invest in technology is the result of a competitive and globalized market that demands quality, efficiency, better products, services and processes. Innovation differentiates research groups and companies; increases market share, profitability and the level of employment and income; adds value to products and services; broadens the relationship with new markets, opens doors to new partnerships and new knowledge and even improves the position in the market. Given this, Minas Gerais is ahead due to the interest of researchers and professionals, as well as incentive due to the existing demand.
\end{abstract}

Technological innovation is a current and relevant issue in the face of global perspectives. In order to do so, the growth of the countries is through investment in research, development and innovation. The federal government, through the Ministry of Science, Technology and Innovation (MCTI), uses this mechanism to encourage investments in innovation by the private sector. With this, it seeks to bring companies closer to universities and research institutes, boosting results in R \& D. The state of Minas Gerais is, therefore, in a prominent position. The State Secretariat for Science, Technology and Higher Education (Sectes) allied to the development and economic growth of the state has made efforts to articulate all the actors that integrate the innovation ecosystem, in addition to creating opportunities for the expansion of the sector. Several initiatives contribute to the strengthening of the innovation ecosystem, which brings benefits to the state and population. Today, several actions and programs that involve the concept are under development in Minas Gerais. One of them is SEED - Startups and Entrepreneurship Ecosystem Development - program that develops the culture of entrepreneurship and the ecosystem of startups in the state. Another important step to stimulate the creation and installation of these companies in Minas Gerais is the opening of technological parks, complexes that bring technology-based companies, universities and other research and development centers in the same space. The objective is to encourage technological innovation by providing shared infrastructure and services and by promoting interactions between the institutions within it. Minas Gerais currently has three parks in operation (Belo Horizonte, Viçosa and Itajubá) and three in operation (Lavras, Juiz de Fora and Uberaba) [1].

The activities of Research and Development of Technological Innovation must in particular ensure application in society. The concept of Research and Development of Technological Innovation is very broad. With this, it is relevant to understand the differences between basic and applied research and experimental development. It is considered, therefore, that to be considered technological innovation must have a new product or process of manufacture, as well as the aggregation of new functionalities or characteristics to the product or process that implies incremental improvements and effective gain of quality or productivity, resulting in greater competitiveness in the market. The state of Minas Gerais has different types of companies, which due to the economic crisis experienced need technological innovation as a primordial methodology for their survival. This allows to foster development and competitiveness. The globalized market demands quality, efficiency, better products, services and processes. In this way technological innovation has become fundamental to profitability, adding value to products and services, new knowledge, and improving market positioning. Investing in the most appropriate technology is essential for good results [2].

The state of minas gerais has its nucleus of innovation. The nucleus is an initiative of the entrepreneurial mobilization for innovation (MEI), an initiative of the national confederation of industries (CNI) to double the number of innovative companies in the country in four years. In addition, the foundation for research support of the state of minas gerais (FAPEMIG), due to the growing demand, has issued specific calls for research support and innovative solutions, which provide incentives for innovation and scientific and technological research. In its demands it invites interested parties to present proposals for technological and innovative solutions to obtain technical and financial support. In the line of development "technological innovation" are all the modalities that aim to encourage dialogue between academia and industry, transforming knowledge into wealth for the country. Innovation programs were established, proinnovation: inventive program, program of support to companies in technology parks - proptec and amitec program [3]. In addition to calls

*Correspondence to: Fernando de Pilla Varotti, Núcleo de Pesquisa em Química Biológica, Universidade Federal de São João del-Rei, Divinópolis, Brazil, Tel: 5537991360377; E-mail: MG.*varotti@ufsj.edu.br ; varotti@ufsj.edu.br

Key words: technology, innovation, development, research

Received: July 15, 2018; Accepted: July 25, 2018; Published: July 28, 2018 
for proposals (call: 04/2017 - support to the nucleus of technological innovation, 10/2017 support for research and innovative solutions in the area of information technology and communication).

From September 15 to 17, 2017, it was held on 3 fair Inova Minas 2017 with the objective of presenting technological innovations produced in Minas, in Praça da Liberdade, in Belo Horizonte, Minas Gerais. The objective of this was to show that the science produced in the state has an impact on the economy and generates income opportunities. This event was also supported by Fapemig, with support from the Minas Gerais Innovation System (SIMI) and the Secretariat of State for Economic Development, Science, Technology and Higher Education (Sedectes) [4]

Legislation also encourages this action, Law 11,196 / 05, now known as the "Law of Good," creates the concession of tax incentives to legal entities that carry out research and development of technological innovation [5]. This demonstrates the importance of technological innovation.

The Startups Acceleration Program of the Federation of Industries of the State of Minas Gerais (FIEMG), aims to create successful businesses and inspire industry and the economy of Minas Gerais. This approach is to connect startups to partners, researchers, industries, customers and the traditional market. Aiming to transform ideas into businesses that generate value to society. More than a trend, being close to the technological revolution is guaranteeing learning and agility in the present and shaping a future where we will be protagonists of change. Companies like Tigre, Coca-Cola, General Eletrics, Bradesco, Uniliver and Disney are some examples of large corporations that embrace the new through acceleration programs and do not see startups as threats. The culture of innovation and agility in the development of new services, reality of the daily life of startups, are attitudes that need to be incorporated in the industrial sector and throughout the economy of Minas Gerais. The whole ecosystem wins when there is support for innovation: entrepreneurs create impact solutions that make a difference for people, institutions and society. Large companies can subsidize startups, as well as benefit from digitization and diversification. It is the union of forces and the exchange of experiences that lead us to evolve [6].
The 1st Workshop on Technological Innovation (WITEC), took place from March 16 to 22, 2015, and had the motto "Why Innovate, it is necessary!". In this it was discussed that we must stop competing and start working collaboratively. In addition, it is important to create cooperative environments between the academic community and the business world. This was therefore the proposal of the 1st WITEC, to bring together people involved in the country's innovation process so that they can collaborate and seek solutions that help the country to create opportunities and transform ideas into actions [7].

The Government of Minas Gerais discussed the Legal Framework of Science, Technology and Innovation on September 27, 2017. The Government of the State of Minas Gerais, in partnership with the Federal University of Minas Gerais (UFMG), through the Secretaria de Estado de Casa Civil and Institutional Relations (Seccri), held, on September 28, 2017 the "Mines in Dialogue Journeys to the Legal Framework of CT \& I in Mines", with the aim of building the State Framework for Science, Technology and Innovation [8]. In this way, Minas Gerais became competitive due to the great demand and interest of researchers with a technological innovation profile

\section{Conclusion}

Companies and research focused on C \& T and innovation need to be in constant contact with sources of knowledge, such as universities. With the support of these initiatives, the State of Minas Gerais is increasingly projected on the international scene. When this occurs, we have a sustainable economic development, since these products have a greater chance of global competition.

\section{References}

1. AGENCIA MINAS (2017)

2. STEFANINI (2017)

3. FAPEMIG (2017) Inovação Tecnológica.

4. GLOBO (2017) Fair presents technological innovations produced in Minas Gerais, Minas Gerais

5. MCTI (2017)

6. FIEMG (2017)

7. http://www.fiemglab.com.br/

8. http://www.fapemig.br/visualizacao-de-noticias/ler/1133/governo-de-minas-discutemarco-legal-da-ciencia-tecnologia-e-inovacao

Copyright: (C2018 Luisa da Fonseca A. This is an open-access article distributed under the terms of the Creative Commons Attribution License, which permits unrestricted use, distribution, and reproduction in any medium, provided the original author and source are credited. 